\title{
Urban employment in post-transition economies: skill mismatch in the local labor market*
}

\author{
Jelena J. Stanković1 , Marija Džunić2 ${ }^{2}$ Srđan Marinković ${ }^{3}$
}

\begin{abstract}
The paper explores the mismatch between the skills and qualifications required by the labour market and those acquired through education and on-the-job learning. The skill mismatch in transition economies tends to be even more pronounced as the labour markets in these countries are characterized by structural unemployment, affecting both older workers with obsolete skills and the young ones. Employers face poor incentives for investing in workforce skill development, due to the inadequate investment climate and volatile business environment. Transition countries face increasing outward mobility of an educated workforce, loss of human capital, and shortage of workforce in the fields such as ICT, medicine, science and research. The research is based on empirical data generated in a survey on ICT and manufacturing enterprises in the City of Niš, Serbia. The research methodology combines workers' self-assessment method for the skill gap measurement and the competence approach combined with the statistical methods. The findings indicate the presence of a qualification mismatch, in the form of the over-qualification as a dominant irregularity in the analysed labour market. The results of the study are expected to contribute to creating a network of policy instrumentaria that tend to be effective on a sub-national level in addressing the mismatch.
\end{abstract}

Key words: education, labour market, skill mismatch, unemployment

JEL classification: J24, C10, R23

\footnotetext{
* Received: 11-05-2021; accepted: 26-12-2021

1 Full Professor, University of Niš, Faculty of Economics, Department of Accounting, Mathematics and Informatics, Trg kralja Aleksandra Ujedinitelja 11, 18000 Niš, Serbia. Scientific affiliation: mathematics and statistics in economics. Phone: +38118528655. E-mail: jelena.stankovic@ eknfak.ni.ac.rs.

${ }^{2}$ Full Professor, University of Niš, Faculty of Economics, Department of General Economic Theory, Trg kralja Aleksandra Ujedinitelja 11, 18000 Niš, Serbia. Scientific affiliation: general economic theory.Phone: +38118528683.E-mail:marija_dzunic@ni.ac.rs.

${ }^{3}$ Full Professor, University of Niš, Faculty of Economics, Department of National Economy and Finance, Trg kralja Aleksandra Ujedinitelja 11, 18000 Niš, Serbia. Scientific affiliation: finance, banking and insurance. Phone: +38118528604.E-mail: srdjan.marinkovic@eknfak.ni.ac.rs.
} 


\section{Introduction}

The labour market mismatch is a common phenomenon in market economies, generated by a number of causes - economic shocks, imperfect information, technology advancements. However, its appearance is most often assigned to the imperfect ability of education systems to respond to the increasing demands for new skills in the conditions of rapid technological and organizational development. The skill mismatch, commonly described as a situation where an employee's skills exceed or lag behind those required by the job, is an inexhaustible research subject across a wide range of fields, as well as a topic of critical concern for policymakers. Despite the extensive literature on the subject, many aspects and the key concepts of the skills mismatch are still quite ambiguous and fragmentary. The body of evidence on skill mismatch is vast, covering various types of mismatches, although not always providing firm conclusions and efficient policy responses aimed at reducing social and economic costs of skills waste.

The research in this paper aimed to contribute to the literature on the labour market inefficiencies in post-transition economies provide analysis of data on skill mismatch collected at the sub-national level in the Republic of Serbia and discusses the results obtained through a comparative analysis of the existence of skills mismatches in other post-transition economies. Unlike developed countries, where the key source of the increasing skill gaps can be related to the globalisation process and technological innovation, the transition economies have faced far more intense labour market changes caused by the overall transformation and the structural changes of the economic systems. As human capital appears to be a crucial resource that underpins the economic growth in these countries, the issue of enhancing work skills and improving the skill base is imposed as a task of critical importance. The analysis of the mismatch is a complex task, given its multidimensional nature and the multiple levels it is performed at. This research is designed as an attempt to address the gap in data and research evidence on a skill mismatch within a single city framework in a post-transition economy. Based on the up-to-date survey data on skills and qualifications of employees, as well as job requirements in a local economic environment, the paper tests the assumption of an existing mismatch in a local labour market. The main objective of the paper is to determine the extent of the existing skill and qualification mismatches in the companies with the largest share of employment in the local economy that has been experiencing a significant increase of employee numbers in recent years. In addition, the research is aimed to explore the importance of various sets of business skills from the perspective of the employee. Therefore, the research presented in the paper will test the following hypothesis: an existing mismatch in a local labour market in post-transition economy records significantly higher values in the number of overqualified workers than the developed labour markets of the European Union. 
The paper is structured as follows: after introductory notes, a literature review on defining and measuring skill mismatch will be presented. In the next section, proposed methodology and data sources used in the paper will be described, followed by the presentation and discussion of main results. Finally, some concluding remarks will be offered.

\section{Literature review}

The concept of skill refers to the ability of an individual to perform tasks required by a particular job. It is a multidimensional concept, including educational attainment, qualifications, and specific competencies (Gambin et al., 2016). Skills are individual characteristics augmented through different types of investment that can generate productive value. Several distinct types of skills can be distinguished such as firm-specific, non-transferable and generic skills that can be transferred across occupations (Becker, 1962). This distinction is especially important from the aspect of education and training, and more particularly, the funding of these activities. Firm-specific skills can be valuable only in the firm where an individual works, unlike general skills, transferable to other firms (Stevens, 1994). Human capital productivity depends not only on the higher education system, but on its mutual reinforcement with life-long skill development, work experience, and other intangible categories such as motivation and work ethic (Mbonigaba and Wilfred, 2019).

The neoclassical model of human capital implies that any investment in enhancing individual skills should be rewarded by the increased wage. This way, the wages would reflect the demand for skills, and in a perfect labour market, the market forces would lead to the equilibrium level of skills, as skill shortages in particular areas would push up wages and attract more individuals to develop skills in these areas. However, as the labour markets are not perfect, they respond slowly to signals about the supply and demand of skills, which leads to sub-optimal human capital allocation and skills supply (Willson and Hogarth, 2003). According to the neoclassical theory, an imbalance between the labour supply and demand is a transitory phenomenon that can be resolved by upward or downward wage flexibility. When the employees' skills are insufficient compared to the job requirements, the underemployed workers used at the existing wages cannot meet the job requirements.. Therefore, "the skills mismatch represents a departure from traditional wage differentials across skill groups" (Handel, 2003).

The labour market mismatch is not an unusual phenomenon in market economies (McGuinness, 2006). It is defined as the situation of imbalance where the level or type of skills available does not correspond to labour market needs (CEDEFOP, 2018). The mismatch between the available skills and skills required by the job 
can appear in terms of over-skilling, under-skilling, over-qualification, underqualification, skill gaps, and skill shortages (European Commission, 2015). There is conclusive empirical evidence that the mismatch affects labour productivity through inefficient resource allocation (McGowan and Andrews, 2015), but also reduces the labour market efficiency by raising frictional and structural unemployment (Petrolongo and Pissarides, 2001).

Numerous and various factors cause the imbalance between the demand and the supply of qualifications and skills.. These causes can be either demand-side or supply-side issues. It can be induced by temporary factors, such as economic shocks, imperfect information, or technological and organizational improvements. Others can be assigned to the information asymmetry - due to the lack of information about the opportunities at the labour market, actors are prone to making sub-optimal choices. Technological and organizational improvements may cause skill obsolescence if the employees cannot adapt to the changes (Robst, 1995). Several causes of skill mismatch are closely related to insufficient training. There are certain barriers to the investment in training - capital or credit constraints, or the reluctance of employers to invest in employee training (Winterbotham et al., 2014). Sometimes the training systems are not designed in a way to easily adapt to the changes in skill demand and cannot respond to the changes in the labour market. Intergenerational or geographical mobility can also cause frictions in the labour market. There are indications that the expansion in higher education that results in the increased average formal schooling level of employees positively affects the education-job matches on the regional labour market. In other words, an increase in companies' workforce average schooling level decreases the probability that companies report mismatch (Cabus and Somers, 2018). Similarly, the recent research on the education mismatch in local labour markets indicates that the circumstances in these markets have significant effects on enrolment rates in higher education institutions and should be considered by the education policies in preventing the mismatch (Ortiz et al., 2020).

The horizontal mismatch exists when the qualification an employee has in a field of study does not match the qualification required by the job. If the qualification of an employee is above or below the required skill level, a vertical mismatch occurs. In recent years, the most pronounced problems concerning the discrepancy between the education systems and labour market requirements appear to be overeducation and over skilling (Sloane and Mavromaras, 2020). One of the methods for measuring the mismatch is the comparison of the share of unemployed people with a certain level of educational attainment to the share of employed people with the same education level (Gatelli and Johansen, 2012). Although it is relatively easy to measure the qualification mismatch, it does not reflect entirely the imbalance between the available and required skills - skills gained beyond formal education, the quality of different education and training systems, as well as skill development 
on the job and life-long learning (Green and McIntosh, 2007). The vertical mismatch is present in all economies where the creation of new jobs causes the demand for new skills in comparison to those required by the jobs that no longer exist. This is especially the case with transition economies, taking into account a number of jobs destroyed in the process of economic restructuring (Sondergaard and Murthi, 2012).

The labour markets in transition countries are characterized by chronic unemployment that affects both older workers with obsolete skills and the young ones, as indicated by particularly high youth unemployment rates (Kolev and Saget, 2005). In the conditions of rapid technological development, old skills required in disappearing industries become redundant (Commander and Kollo, 2008). In addition, the poor investment climate and volatile business environment create poor incentives for the employers in transition countries for investing in the skill development of the employees. The number of transition countries with poor economic performance faces increasing outward mobility of educated workforce (the so-called brain-drain) causing a significant skill mismatch within certain occupations (Hars and Simons, 2016). One of the reasons for the persistent skill mismatch in the transition economies is the inability of education systems in these countries to adapt to the new requirements of the labour market, accompanied by low public investments in education, that has also contributed to reducing the available stock of human capital (Sondergaard and Murthi, 2012). Dual training and promotion of work-based life-long learning is one of the generally accepted approaches to improving the match between workforce skills and labour market demands (Šćepanović and Martín Artiles, 2020), but insufficiently developed in the post-transition countries.

An indicator of skill shortages or surpluses that is often used in economic research relates to the measurement of wage differentiation or the wage growth that can indicate the existence of the skill mismatch in the long run. However, in the short run, one of the regularly used mismatch measures is obtained through the employee surveys, where the employees report, based on their self-assessment, whether they are sufficiently skilled for their current jobs or whether they can use their existing skills on the job (Elias and Purcell, 2004). The qualification mismatch is measured based on the opinions of workers about the match between their job and the level of acquired education (Dorn and Sousa-Poza, 2005). The skill mismatch is determined by comparing the self-assessed skill levels of the employees and the levels required for the job. This method covers measuring a wide range of skills, but it often cannot identify the specific skills deficits.

The rationale for this method of measuring the mismatch is the assumption that the employees themselves are able to assess the extent to which they possess the skills necessary to undertake their jobs, or the skills and qualifications needed to get/perform the job. There are two issues regarding the reliability of data collected 
this way. First, the employees tend to often overstate the availability of their skills, causing an upward bias of the skill surplus estimate, or the downward bias of the skill gap (Mason and Wilson, 2003). This way, over-skilling appears much more often compared to under-skilling (Alen and Van der Velden, 2001). Second, such data may indicate employees' transition in the labour market, from the initial lowpaid job to the job in line with their qualifications, instead of measuring the real mismatch. Also, the context of the questions or the impact of some exogenous factors can affect the reliability of the responses.

\section{Research methodology}

Methodologies of skill mismatch measurement typically refer to the quantification of particular professional characteristics, educational level, qualifications, and specific competencies (literacy, numeracy, foreign languages, IT skills, etc.) required for the job, compared to the skills of the individuals employed or interested for the job. Thus, the measure of skill mismatch is the degree to which employees possess skills or education/qualifications at levels that are sufficient, insufficient, or poorly connected to their current job requirements (Quintini, 2011; Ramos et al., 2012).

Occupational skills encompass various dimensions which are difficult to measure in practice. The attempts for developing efficient models for measuring the skill mismatch have led to a significant number of papers in the contemporary literature addressing this problem, as well as to the development of measurement methodologies by various international institutions. The basic categorization of skills, according to the European Commission measurement methodology, includes basic skills, transversal skills, and vocational skills (CEDEFOP, 2018). Similarly, the methodology used by UNESCO includes almost the same groups of skills foundation skills, transferable skills, and technical and vocational skills associated with specific occupations (UNESCO, 2012). A slightly more detailed approach is provided by the ILO, which classifies all relevant skills into four groups foundation skills or basic skills, professional or personal skills, transferable skills or core work skills, and technical and vocational skills (Brewer, 2013). USAID methodology of determining the skills mismatch includes sets of skills such as soft skills, academic skills, and technical skills (Lipman et al., 2015). The skill mismatch assessment models used by the OECD and the World Bank have such an approach that basic skills and cognitive skills are analysed within the same group. OECD model encompasses basic foundational i.e. cognitive skills, social and emotional skills, and vocational skills (OECD, 2012; OECD, 2014; OECD, 2015), while the model used in World Bank research includes cognitive skills, behavioural skills, and technical skills. 
Figure 1: Model flowchart

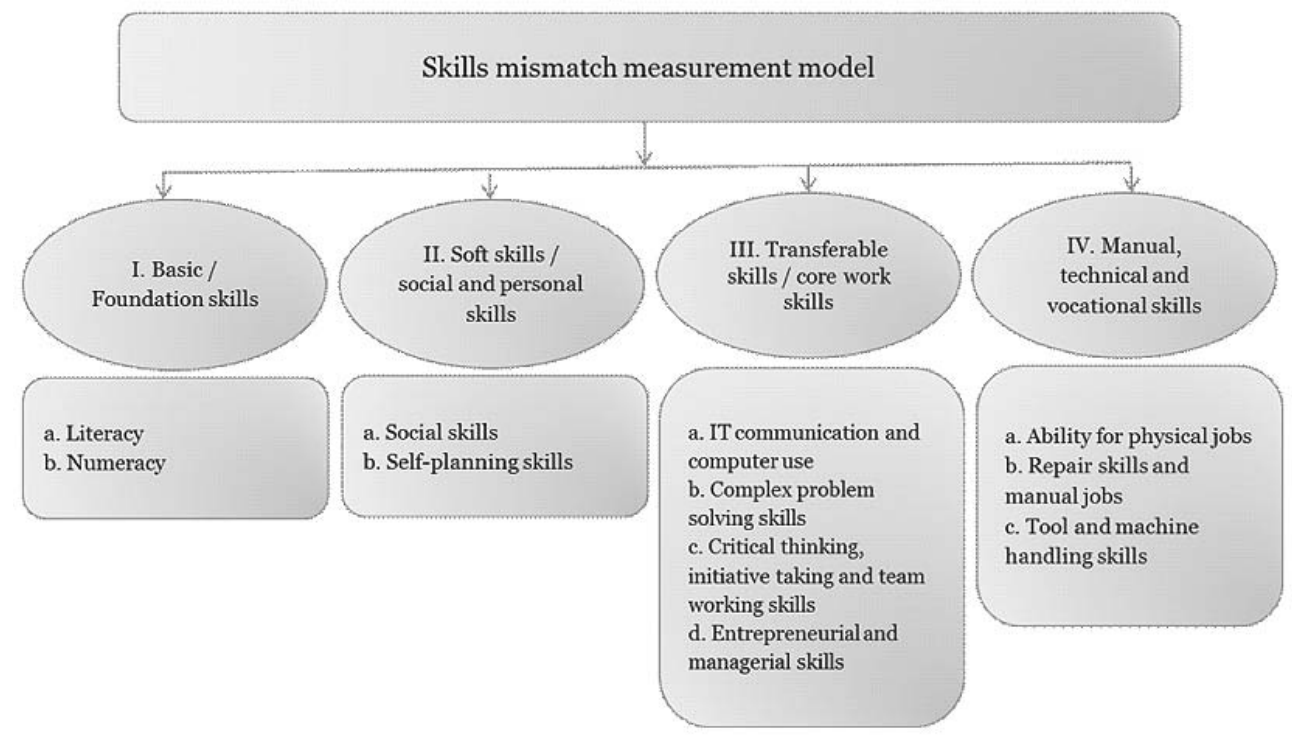

Source: Authors' preview

The model developed for measuring skill mismatch in this research combines approaches used by European Commission (CEDEFOP, 2018) and International Labour Office (Brewer, 2013) and include four different groups of skills (Figure 1):

i. Basic or foundation skills which include literacy and numeracy;

ii. Soft skills or social and personal skills that include social skills and selfplanning skills;

iii. Transferable skills or core work skills that comprise IT communication and computer use, complex problem-solving skills i.e. analytical skills, critical thinking, initiative taking and team working skills, entrepreneurial and managerial skills;

iv. Manual, technical and vocational skills that encompass ability for physical jobs, repair skills and manual jobs and tool and machine handling skills.

\section{Empirical data and analysis}

This research focuses on enterprises from different industries (food production and processing, recycling, electrical industry, machine industry, defence industry and high-tech equipment) operating in the City of Niš, Serbia. The empirical research 
and data collection is conducted within the research project of the Serbian Academy of Sciences and Arts (SASA) in 2019 (March 22 - December 22, 2019). The sample includes privately owned, small and medium-sized enterprises, employing a total number of 2,309 workers. These are the companies that have been experiencing the upward trend in the number of employees in recent years and as such have constant requirements for jobs with specific knowledge and skills. According to Agency for Business Registers (2019) data, in the previous three years, surveyed companies from food processing industry have shown a slight increase in the number of employees (3\%), companies belonging to machine industry have increased their number of employees for $16.88 \%$, while enterprises belonging to the hightechnologies and electrical industries show a growth in the number of employees of $197 \%$. For the same period, asset growth in food processing enterprises was $20.27 \%$, high-technologies and electrical industries 33.03\%, machine industry $27.29 \%$, and recycling industry recorded asset growth of $7.69 \%$.

One of the characteristics of the post-transition period in the Serbian economy is the pronounced process of de-industrialization with low rates of industrial production and decreasing number of employees (Savić, 2014). Therefore, the aim of this research is to explore the skill mismatch in one segment of the local labour market, comparing the available skills with requirements of the industrial companies that report increasing performance indicators and continuous growth in the number of employees.

Aiming at gathering relevant data to identify skill mismatches defined by the model presented in the previous section, an empirical survey has been conducted. The survey methodology is founded on contemporary research that utilises worker self-assessment as a methodological approach to collecting data on horizontal and vertical mismatches. Programme for the International Assessment of Adult Competencies (PIAAC) and Survey of Adult Skills, as a key element of OECD empirical approach to measuring skill mismatch, explore the skill gaps based on employees' self-assessment, especially the ability to deploy and develop skills required for the job at performance satisfactory level (Pellizzari and Fichen, 2013; Pouliakas and Russo, 2015). Workers Self-Assessment (WA) and Competence Approach for assessment of overeducation are often used for collecting data regarding skill shortages and skill gaps (Gambin et al., 2018; ILO, 2017; ILO, 2018a; ILO, 2018b).

The survey conducted for the purpose of this paper draws upon the methodology used in the Skills and Employment Survey, conducted by the University of Cardiff (Felstead et al., 2012). The data were collected as part of continuous research activities of the Serbian Academy of Sciences and Arts - Branch in Niš. The survey questionnaire consists of one hundred and fifty questions covering all four skill groups listed in the model. Each skill group was assessed through a series of questions, which provided information on the importance of those skills 
for performing a particular job, the skills required to perform a particular job at a satisfactory level, as well as the skills that the interviewed employee owns. Empirical data collection was conducted through a questionnaire or a guided questionnaire, depending on the educational structures of the respondents and the type of jobs.

The sample includes slightly less than $10 \%$ of the total number of employees in the surveyed companies, i.e., 214 workers employed in the food processing industry, electrical and mechanical engineering industry, high-technologies industries, and recycling. Formed on the principles of random sampling, it covers all educational profiles of employees and job types. Male respondents make $57.5 \%$ of the sample, while $42.1 \%$ are female (Table 1 ).

Table 1: Structure of the sample

\begin{tabular}{|c|c|c|c|c|c|}
\hline & & Frequency & Percent & $\begin{array}{c}\text { Valid } \\
\text { Percent }\end{array}$ & $\begin{array}{c}\text { Cumulative } \\
\text { Percent }\end{array}$ \\
\hline \multicolumn{6}{|c|}{ Gender } \\
\hline \multirow[t]{4}{*}{ Valid } & No answer & 1 & 0.5 & 0.5 & 0.5 \\
\hline & Male & 123 & 57.5 & 57.5 & 57.9 \\
\hline & Female & 90 & 42.1 & 42.1 & 100.0 \\
\hline & Total & 214 & 100.0 & 100.0 & \\
\hline \multicolumn{6}{|c|}{ Professional Qualifications } \\
\hline \multirow[t]{7}{*}{ Valid } & No qualifications & 1 & 0.5 & 0.5 & 0.5 \\
\hline & $\begin{array}{l}\text { General qualifications } \\
\text { (primary and lower secondary } \\
\text { education) }\end{array}$ & 17 & 7.9 & 7.9 & 8.4 \\
\hline & $\begin{array}{l}\text { Professional qualifications } \\
\text { (upper secondary, vocational } \\
\text { secondary) }\end{array}$ & 86 & 40.2 & 40.2 & 48.6 \\
\hline & Academic qualifications & 85 & 39.7 & 39.7 & 88.3 \\
\hline & $\begin{array}{l}\text { Vocational qualifications } \\
\text { (vocational studies) }\end{array}$ & 10 & 4.7 & 4.7 & 93.0 \\
\hline & Refuse to answer & 15 & 7.0 & 7.0 & 100.0 \\
\hline & Total & 214 & 100.0 & 100.0 & \\
\hline
\end{tabular}

Source: Authors' calculation

Most respondents have professional (40.2\%) or academic qualifications (39.7\%), where professional qualification encompasses upper secondary and vocational secondary education, while academic qualifications refer to higher education (Table 1). The average age of the respondents in the sample is 40.9 years (minimum 22, maximum 67 years, std. deviation 10.499). 
The results cover two specific research outcomes: (1) identifying skills of the highest importance for performing the job at a satisfactory performance level, and (2) identifying vertical skill mismatch - the existence of over-qualification or under-qualification of employees.

The first part of the results is presented in Table 2 and indicates that the most important skills regarding employment in observed industrial companies are transferable skills or core work skills (average assessment 3.9814). The crucial skills within the group are critical thinking, initiative-taking, and team working skills, followed by complex problem-solving skills (Table 2). Even though it is industrial production, manual, technical, and vocational skills are perceived as the least important for successful job performance. This can be explained by the information that these are high-technology intensive industries, where physical labour is not intensively utilized. It is interesting to note that IT communication and computer use are rated at the level of importance of basic skills, i.e. below the level of importance of the core work skills.

Table 2: Importance of skills for the job: Workers self-assessment in scale 1 to 5

\begin{tabular}{|c|c|c|c|c|c|}
\cline { 2 - 6 } \multicolumn{1}{c|}{} & $\mathrm{N}$ & Minimum & Maximum & Mean & $\begin{array}{c}\text { Std. } \\
\text { Deviation }\end{array}$ \\
\hline Basic/Foundation skills & 165 & 1 & 5 & 3.1747 & 0.84765 \\
\hline a. Literacy & 165 & 1 & 5 & 3.1697 & 0.9264 \\
\hline b. Numeracy & 214 & 1 & 5 & 3.0234 & 1.17529 \\
\hline Soft skills/Social and personal skills & 214 & 1.64 & 5 & 3.5822 & 0.73105 \\
\hline a. Social skills & 214 & 1.56 & 5 & 3.5452 & 0.76178 \\
\hline b. Self-planning skills & 214 & 1 & 5 & 3.6192 & 0.86287 \\
\hline Transferable skills/Core work skills & 186 & 1.67 & 5 & 3.9814 & 0.71618 \\
\hline $\begin{array}{c}\text { a. IT communication and } \\
\text { computer use }\end{array}$ & 210 & 1 & 5 & 3.51 & 1.381 \\
\hline b. Complex problem-solving skills & 214 & 1.67 & 5 & 3.7329 & 0.78434 \\
\hline $\begin{array}{c}\text { c. } \text { Critical thinking, initiative } \\
\text { taking and team working skills }\end{array}$ & 194 & 1.67 & 5 & 3.9835 & 0.89397 \\
\hline $\begin{array}{c}\text { d. Entrepreneurial and } \\
\text { managerial skills }\end{array}$ & 95 & 1 & 5 & 3.6695 & 1.04241 \\
\hline $\begin{array}{l}\text { Manual, technical and vocational } \\
\text { skills }\end{array}$ & 214 & 1 & 5 & 2.7301 & 1.13931 \\
\hline a. Ability for physical jobs & 214 & 1 & 5 & 2.25 & 1.223 \\
\hline b. Repair skills and manual jobs & 214 & 1 & 5 & 3.07 & 1.492 \\
\hline $\begin{array}{c}\text { c. Tool and machine handling } \\
\text { skills }\end{array}$ & 214 & 1 & 5 & 3.12 & 1.49 \\
\hline
\end{tabular}


Assessment of skill mismatch was provided by determining the difference in the levels of qualifications, required to perform a particular job, and the qualifications held by the employee performing the job. At the sample level, there is a clear overqualification of employees (Table 3), where the average assessment of qualification required for the job (3.23, on a scale of 1 to 5$)$ is lower than employee's qualification (3.63, on a scale of 1 to 5$)$.

Table 3: Mismatch assessment - Means

\begin{tabular}{|l|c|c|c|c|c|}
\hline & $\mathrm{N}$ & Mean & $\begin{array}{c}\text { Std. } \\
\text { Deviation }\end{array}$ & Minimum & Maximum \\
\hline Qualification required for the job & 186 & 3.23 & 1.073 & 1 & 5 \\
\hline Employee's qualification & 186 & 3.63 & 0.979 & 1 & 5 \\
\hline
\end{tabular}

Source: Authors' calculation

The results in Table 4 show that a qualification mismatch concerns 39.8 percent of respondents, of whom 28.5 percent are over-qualified, while 11.3 percent are under-qualified.The results referring to over-qualification are comparable to other non-EU post-transition economies such as Ukraine and Armenia, where the incidence of over-education among urban working-age population is 29.1 percent (Kupets, 2015b). North Macedonia compares favourably with the share of overqualified employees at 20.7 percent (Kupets, 2015b). A significant share of overqualified or over-educated workers in workforce in post-transition economies can be explained by the fact that the high levels of formal education in these countries do not necessarily translate into high levels of up-to-date productive skills (Kupets, 2015a).

Table 4: Mismatch assessment - Ranks

\begin{tabular}{|l|l|c|c|c|}
\cline { 3 - 5 } \multicolumn{2}{c|}{} & $\mathrm{N}$ & Mean Rank & Sum of Ranks \\
\hline \multirow{3}{*}{$\begin{array}{l}\text { Employee's qualification - } \\
\text { Qualification required for the } \\
\text { job }\end{array}$} & Negative Ranks & $21^{\mathrm{a}}$ & 30,79 & 646,50 \\
\cline { 2 - 5 } & Positive Ranks & $53^{\mathrm{b}}$ & 40,16 & 2128,50 \\
\cline { 2 - 5 } & Ties & $112^{\mathrm{c}}$ & & \\
\cline { 2 - 5 } & Total & 186 & & \\
\hline
\end{tabular}

a. Employee's qualification $<$ Qualification required for the job;

b. Employee's qualification $>$ Qualification required for the job;

c. Employee's qualification $=$ Qualification required for the job

Source: Authors' calculation 


\section{Results and discussion}

Compared to the developed economies, results of qualification mismatch presented in this paper differ significantly. The share of over-qualified employees in the European Union is $14.7 \%$ and under-qualified $18.7 \%$, while in OECD countries these percentages are $16.8 \%$ for over-qualification and $18.9 \%$ for under-qualification (OECD.Stat, 2016). According to the data on the qualification mismatch in posttransition economies that are EU members, it can be concluded that the results of this research related to under-qualification of workers are comparable to underqualification percentages in those countries (Figure 2). However, in terms of overqualification, the results obtained in this study clearly indicate a significantly higher percentage of workers with a higher level of qualifications than the one required for the job they are performing.

Figure 2: Comparative preview: Share of overqualified and underqualified urban workforce in post-transitional EU countries and Serbia

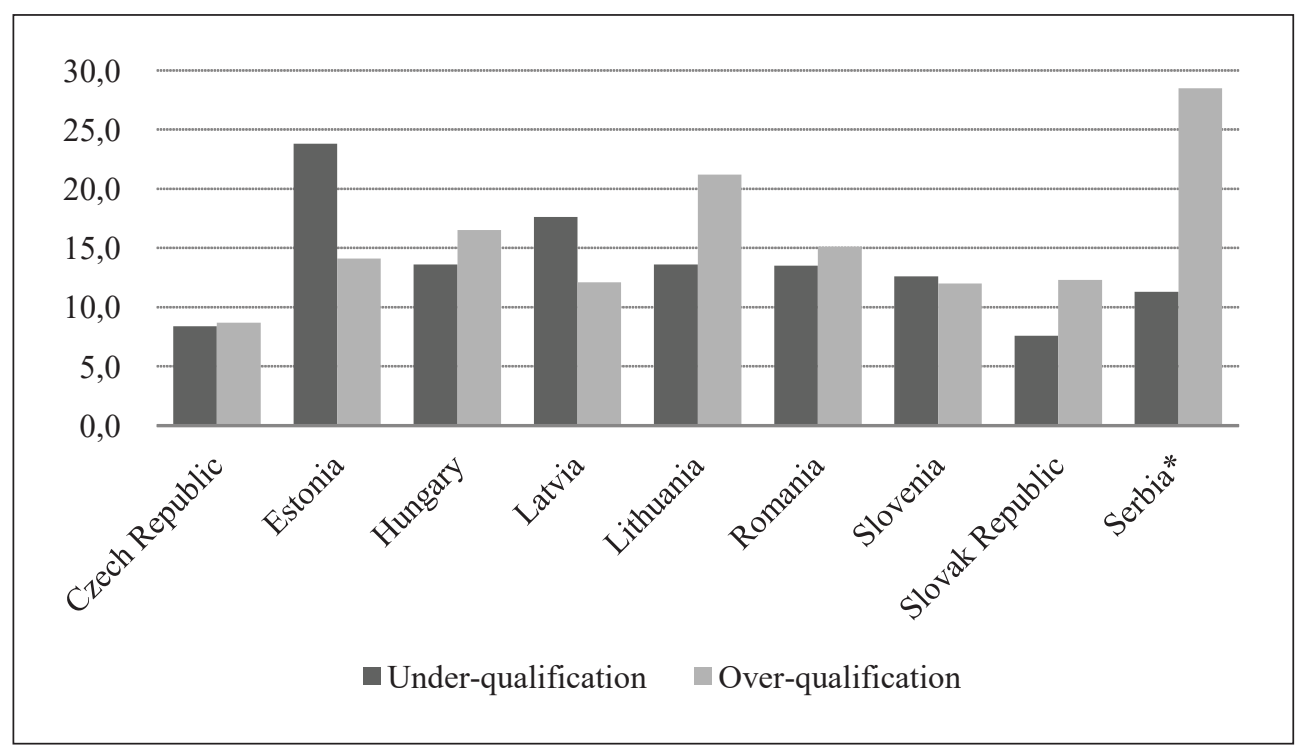

*Data generated in this research, at sub-national level

Source: OECD.Stat, 2016

Comparable findings for non-EU post-transition countries are presented by Kupets (2015a, 2015b). A similar conclusion is provided by Bartlett (2013), based on the evidence for the emerging market economies, implying that the highest rate of skill mismatch is among highly educated university graduates, especially male graduates. 
Government structures in the Republic of Serbia often use educational attainment data as one of the country's key competitive advantages for attracting foreign direct investment and accelerating innovation. However, the quantitative indicators related to the share of highly educated should be treated with certain reserve especially at the sub-national level, taking into account the result of the analysis where the percentage of over-education among research groups indicates dispersion informal educational level from real knowledge and skills that can be materialized in the labour market.

\section{Conclusion}

Findings in the research indicate that the most important category of skills in the observed industries are transferable skills or core work skills (average importance in workers self-assessment is 3.9814 on a scale of 1 to 5). As a dominant irregularity at the local labour market, the existence of qualification mismatch is determined, with the prevailing over-qualification, i.e. over-education (28.5 percent of the surveyed employees had a higher level of qualifications than the one required for the job). The causes of pronounced over-education in the labour market can be viewed from two perspectives. The first relates to unattractive job offers, including the unwillingness or inability of employers to offer competitive wages, unsatisfied job quality, or low work conditions, while the second can be regarded as a lack of training and life-long education of the employees.

The scientific contribution of the research in this paper is twofold. In theoretical terms, a model for assessing skill mismatch has been developed based on contemporary models used by relevant international institutions, but also adapted to the specificities of the labour market of post-transition economies. The empirical contribution relates to data collection indicating the level of skill mismatch at the local labour market in one of the largest cities in the Republic of Serbia. This type of research is rare for labour markets in post-transition countries and creating an empirical basis that enables comparison to developed economies (i.e. methodologically is aligned with research conducted in developed economies) is a step forward in this field of research.

The research and conclusions of this paper are limited to the urban labour market of the City of Nis and do not include the services sector. Further research will be focused on a spatially larger sample, but also a wider coverage of economic sectors.

\section{Acknowledgments}

The research in this paper was conducted within the framework of activities on bilateral cooperation project "Researching capacity for implementation of smart 
cities as basis for sustainable urban development" financed by the Ministry of education, science and technological development of the Republic of Serbia and the Ministry of science and education of the Republic of Croatia. Supported by the Ministry of Science, Education and Technological Development of the Republic of Serbia (no. 451-03-68/2020-14/200100) and by the University of Rijeka under the project "Smart Cities in the function of the development of the national economy" (uniri-drustv-18-255-1424).

\section{References}

Allen, J., Van der Velden, R. (2001) "Educational mismatches versus skill mismatches: effects on wages, job satisfaction, and on-the-job search", Oxford Economic Papers, Vol. 53, No. 3, pp. 434-452. https://doi.org/10.1093/oep/53.3.434.

Agency for Business Registers of Republic of Serbia (2019) Financial Statements Database. Available at: https://pretraga3.apr.gov.rs/pretragaObveznikaFI [Accessed: May 9, 2021].

Bartlett, W. (2013) "Skill Mismatch, Education Systems, and Labour Markets in EU Neighbourhood Policy Countries", WP5/20 search working paper. Available at: http://www.ub.edu/searchproject/wp-content/uploads/2013/09/WP05.20.pdf [Accessed: May 9, 2021].

Becker, G. S. (1962) "Investment in Human Capital: A Theoretical Analysis", Journal of Political Economy, Vol. 70, No. 5, pp. 9-49. https://doi.org/10.1086/258724.

Brewer, L. (2013) Enhancing youth employability: What? Why? and How? Guide to core work skills, Geneva: ILO.

Cabus, S., Somers, M. (2018) "Mismatch between education and the labour market in the Netherlands: is it a reality or a myth? The employers' perspective", Studies in Higher Education, Vol. 43, No. 11, pp. 1854-1867. https://doi.org/10. 1080/03075079.2017.1284195.

Cedefop (2018) Insights into skill shortages and skill mismatch: learning from Cedefop's European skills and jobs survey, Luxembourg: Publications Office Cedefop reference series, No 106. https://doi.org/10.2801/645011.

Commander, S., Kollo, J. (2008) "The changing demand for skills - Evidence from the transition", Economics of Transition, Vol. 16, No. 2, pp. 199-221. https:// doi.org/10.1111/j.1468-0351.2008.00303.x.

Dorn, D., Sousa-Poza, A. (2005) „The Determinants of Early Retirement in Switzerland", Swiss Journal of Economics and Statistics, Vol. 141, No. 2, pp. 247-283. https://doi.org/10.5167/uzh-99445.

European Commision (2015) Employment, Social Affairs \& Inclusion: Measuring skills mismatch, Analytical Web Note 7/2015. https://doi.org/10.2767/620480. 
Elias, P., Purcell K. (2004) "Is Mass Higher Education Working? Evidence from the Labour Market Experiences of Recent Graduates", National Institute Economic Review, No. 90, pp. 60-74. https://doi.org/10.1177/002795010419000107.

Felstead, A. et al. (2012) Skills and Employment Survey (SES), project funded by UK Commission for Employment and Skills (UKCES) and Economic and Social Research Council (ESRC), United Kingdom. Available at: https://esrc. ukri.org/research/our-research/skills-and-employment-survey-ses/ [Accessed: December 23, 2021].

Gambin, L. et al. (2016) Research to understand the extent, nature and impact of skills mismatches in the economy, London: Department for Business, Innovation and Skills (Research paper number 265) Available at: https://assets.publishing. service.gov.uk/government/uploads/system/uploads/attachment_data/ file/522980/BIS-16-260-research-skills-mismatches-in-the-economyMay-2016.pdf [Accessed: May 9, 2021].

Gatelli, D., Johansen, J. (2012) Measuring mismatch in ETF partner countries, mimeo, Turin: European Training Foundation. Available at: https:/esrc.ukri.org/ research/our-research/skills-and-employment-survey-ses/ [Accessed: May 9, 2021].

Green, F., McIntosh, S. (2007) "Is There a Genuine Underutilisation of Skills Amongst the Overqualified?" Applied Economics, Vol. 39, pp. 427-439. https:// doi.org/10.1080/00036840500427700.

Handel, M. J. (2003) "Skills Mismatch in the Labour Market" Annual Review of Sociology, No. 29, pp. 135-165. https://doi.org/10.1146/annurev.soc.29.010202. 100030.

Hars, A., D. Simon (2016) "Why do doctors leave - and what would make them stay? On the characteristics of the migration of medical doctors from Hungary" Külgazdaság, Vol. 60, No. 5-6, pp. 3-26.

International Labour Office (2017) World Employment and Social Outlook: Trends 2017. Geneva: ILO. Available at: https://www.ilo.org/wcmsp5/groups/public/--dgreports/---dcomm/---publ/documents/publication/wcms_541211.pdf [Accessed: May 9, 2021].

International Labour Office (2018a) Measurement of qualifications and skills mismatches of persons in employment, ICLS/20/2018/Room document 15, 20th International Conference of Labour Statisticians Geneva. Available at: https:// www.ilo.org/wcmsp5/groups/public/---dgreports/---stat/documents/ meetingdocument/wcms_636052.pdf [Accessed: May 9, 2021].

International Labour Office (2018b) World Employment and Social Outlook: Trends 2018. Geneva: ILO. Available at: https://www.ilo.org/wcmsp5/groups/public/--dgreports/---dcomm/---publ/documents/publication/wcms_615594.pdf [Accessed: May 9, 2021]. 
Kolev, A., Saget, C. (2005) "Understanding youth labour market disadvantage: Evidence from south-east Europe", International Labour Review, Vol. 144, No.

2, pp. 161-175. https://doi.org/10.1111/j.1564-913x.2005.tb00564.x.

Kupets, O. (2015a) Skill mismatch and overeducation in transition economies, IZA World of Labor. Available at: https://wol.iza.org/articles/skill-mismatch-andovereducation-in-transition-economies/long [Accessed: May 9, 2021].

Kupets, O. (2015b) Education in Transition and Job Mismatch: Evidence from the Skills Survey in Non-EU Transition Economies. Kyoto Institute of Economic Research Discussion Paper No. 915. Available at: http://www.kier.kyoto-u.ac. jp/DP/DP915.pdf [Accessed: May 9, 2021].

Lippman, L. et al. (2015) Key Soft Skills that Foster Youth Workforce Success: Toward a Consensus across Fields. Washington: Child Trends. Available at: https://www.childtrends.org/wp-content/uploads/2015/06/201524AWFCSoftSkillsExecSum.pdf [Accessed: May 9, 2021].

Mason, G., Wilson, R. A. (2003) Employers Skill Survey New Analyses and Lessons Learned. Nottingham: Department for Education and Skills. Available at: https://warwick.ac.uk/fac/soc/ier/publications/2003/mason_and_wilson_2003. pdf [Accessed: December 23, 2021].

Mbonigaba, J., Wilfred, A.G. (2019) "Productivity effects of human capital: an empirical investigation of health and higher education in South Africa", Zbornik radova Ekonomskog fakulteta u Rijeci: časopis za ekonomsku teoriju i praksu/ Proceedings of Rijeka Faculty of Economics: Journal of Economics and Business, Vol. 37, No. 1, pp. 277-301. https://doi.org/10.18045/zbefri.2019.1.277.

McGowan, M.A., Andrews, D. (2015) Labor market mismatch and labor productivity. OECD Economics Department Working Papers No. 1209, Paris: OECD Publishing. Available at: https:/www.oecd.org/economy/growth/ Labour-Market-Mismatch-and-Labour-Productivity-Evidence-from-PIAACData.pdf [Accessed: December 23, 2021].

McGuiness, S. (2006) "Overeducation in the Labor Market" Journal of Economic Surveys, Vol. 20, No. 3, pp. 387-418. https://doi.org/10.1111/j.0950-0804. 2006.00284.x.

OECD (2012) Better Skills, Better Jobs, Better Lives: A Strategic Approach to Skills Policies, Paris: OECD Publishing, https://doi.org/10.1787/9789264177338-en.

OECD (2014) Skills Beyond School: Synthesis Report, OECD Reviews of Vocational Education and Training, Paris: OECD Publishing. https://doi. org/10.1787/9789264214682-en.

OECD (2015) Skills for Social Progress: The Power of Social and Emotional Skills, OECD Skills Studies, Paris: OECD Publishing, https://doi.org/10.1787/ 9789264226159-en.

OECD.Stat (2016) Mismatch Datbase. Available at: https://stats.oecd.org/Index. aspx? DataSetCode=MISMATCH [Accessed: May 9, 2021]. 
Ortiz, E. A. et al. (2020) Local Labor Markets and Higher Education Mismatch, IDB working paper series No IDB-WP-01115. Available at: https:// publications.iadb.org/publications/english/document/Local-Labor-Markets-andHigher-Education-Mismatch-What-is-The-Role-of-Public-and-PrivateInstitutions.pdf [Accessed: December 23, 2021].

Petrolongo, B., Pissarides, C. (2001) "Looking into the black box: a survey of the matching function", Journal of Economic Literature, Vol. 39, pp. 390-431. https://doi.org/10.1257/jel.39.2.390.

Pellizzari, M., Fichen, A. (2013) A New Measure of Skills Mismatch: Theory and Evidence from the Survey of Adult Skills (PIAAC), OECD Social, Employment and Migration Working Papers, No. 153, Paris: OECD Publishing, http://dx.doi. org/10.1787/5k3tpt04lcnt-en.

Pouliakas, K., Russo G. (2015) Heterogeneity of Skill Needs and Job Complexity: Evidence from the OECD PIAAC Survey, IZA Discussion Paper 9392. Available at: http://ftp.iza.org/dp9392.pdf [Accessed: May 9, 2021].

Quintini, G. (2011) Over-Qualified or Under-Skilled: A Review of Existing Literature, OECD Social, Employment and Migration Working Paper 121. Available at: https://www.oecd-ilibrary.org/social-issues-migration-health/overqualified-or-under-skilled_5kg58j9d7b6d-en [Accessed: May 9, 2021].

Ramos, R., Surinach, J., Artís, M. (2012) "Regional Economic Growth and Human Capital: The Role of Over-Education", Regional Studies, Vol. 46, No. 10, pp. 1389-1400. https://doi.org/10.1080/00343404.2012.675140.

Robst, J. (1995) "Career Mobility, Job Match, and Overeducation", Eastern Economic Journal, Vol. 2, pp. 539-550.

Savić, Lj. (2014) "New Industrialization in Serbia - Reality or Delusion", Management: Journal for Theory and Practice Management, Vol. 70, pp. 5964. https://doi.org/10.7595/management.fon.2014.0005.

Sloane, P. J., Mavromaras, K. (2020) Overeducation, skill mismatches, and labor market outcomes for college graduates. IZA Institute of Labor Economics. Available at: https://wol.iza.org/articles/overeducation-skill-mismatches-andlabor-market-outcomes-for-college-graduates/long [Accessed: June 27, 2021].

Solutions for Youth Employment (2015) Toward Solutions for Youth Employment. A 2015 Baseline Report. World Bank: Washington. Available at: https://www.ilo. org/wcmsp5/groups/public/---ed_emp/documents/publication/wcms_413826. pdf [Accessed: May 9, 2021].

Šćepanović V., Martín Artiles, A. (2020) "Dual training in Europe: a policy fad or a policy turn?", Transfer: European Review of Labour and Research, Vol. 26, No. 1, pp. 15-26. https://doi.org/10.1177/1024258919898317.

Sondergaard, L., Murthi, M. (2012) Skills, Not Just Diplomas: Managing Education for Results in Eastern Europe and Central Asia, Washington: The World Bank. Available at: https://openknowledge.worldbank.org/bitstream/handle/10986/2368 
/652050REPLACEM061562B09780821380963.pdf?sequence=1\&isAllowed=y [Accessed: December 23, 2021].

Stevens, M. (1994) "Labor Contracts and Efficiency In On-The-Job Training", The Economic Journal, Vol. 104, pp. 408-419. https://doi.org/10.2307/2234760.

UNESCO (2012) EFA Global Monitoring Report 2012. Youth and Skills: Putting Education to Work. Paris: UNESCO. Available at: https://en.unesco.org/gemreport/report/2012/youth-and-skills-putting-education-work [Accessed: May 9, 2021].

Wilson, R. A., Hogarth, T. (2003) Low Skill Trajectories: a review of the evidence and additional analysis. London: Department for Trade and Industry.

Winterbotham, M., D. et al. (2014) The UK Commission's Employer Skills Survey 2013: UK Results, UK Commission for Employment and Skills. Available at:https:/assets.publishing.service.gov.uk/government/uploads/system/uploads/ attachment_data/file/327492/evidence-report-81-ukces-employer-skills-survey13-full-report-final.pdf [Accessed: December 23, 2021].

World Bank (2017) World Development Report 2018: Learning to Realize Education's Promise. World Bank: Washington, DC. Available at: https:// openknowledge.worldbank.org/handle/10986/28340 [Accessed: May 9, 2021]. 


\title{
Urbano zapošljavanje u post-tranzicijskim gospodarstvima: neusklađenost vještina na lokalnom tržištu rada
}

\author{
Jelena J. Stanković ${ }^{1}$, Marija Džunić ${ }^{2}$,Srđan Marinković ${ }^{3}$
}

\begin{abstract}
Sažetak
Ovaj rad istražuje neusklađenost između vještina i kvalifikacija koje zahtijeva tržište rada $i$ onih koje se stječu obrazovanjem $i$ učenjem na radnom mjestu. Neusklađenost vještina u tranzicijskim gospodarstvima ima tendenciju da bude još izraženija budući da tržišta rada u tim zemljama karakterizira strukturna nezaposlenost, koja istovremeno pogađa $i$ starije radnike sa zastarjelim vještinama i mlade. Poslodavci se suočavaju s lošim poticajima za ulaganje u razvoj vještina radne snage zbog neodgovarajuće investicijske klime i nestabilnog poslovnog okruženja. Zemlje u tranziciji suočavaju se sa sve većom vanjskom mobilnošću obrazovane radne snage, gubitkom ljudskog kapitala i nedostatkom radne snage u područjima kao što su ICT, medicina, znanost $i$ istraživanje. Istraživanje se temelji na empirijskim podacima prikupljenim u anketi o ICT-u i proizvodnim poduzećima u gradu Nišu u Srbiji. Metodologija istraživanja kombinira metodu samoprocjene radnika za mjerenje jaza u vještinama i pristup temeljen na kompetencijama $u$ kombinaciji sa statističkim metodama. Nalazi ukazuju na prisutnost kvalifikacijske neuskladenosti, $u$ vidu prekvalificiranosti za posao kao dominantne nepravilnosti na analiziranom tržištu rada. Očekuje se da će rezultati studije doprinijeti stvaranju mreže političkih instrumenata koji imaju tendenciju da budu učinkoviti na podnacionalnoj razini u rješavanju neusklađenosti.
\end{abstract}

Ključne riječi: obrazovanje, tržište rada, neusklađenost vještina, nezaposlenost JEL klasifikacija: J24, C10, R23

1 Redoviti profesor, Univerzitet u Nišu, Ekonomski fakultet, Katedra za računovodstvo, matematiku i informatiku. Trg kralja Aleksandra Ujedinitelja 11, 18000 Niš, Srbija. Znanstveni interes: matematika i statistika u ekonomiji. Tel.: +38118528655. E-mail: jelena.stankovic@ eknfak.ni.ac.rs.

${ }^{2}$ Redoviti profesor, Univerzitet u Nišu, Ekonomski fakultet, Katedra za opštu ekonomsku teoriju, Trg kralja Aleksandra Ujedinitelja 11, 18000 Niš, Srbija. Znanstveni interes: opća ekonomska teorija.Tel.: +38118528683.E-mail:marija_dzunic@ni.ac.rs.

${ }^{3}$ Redoviti profesor, Univerzitet u Nišu, Ekonomski fakultet, Katedra za nacionalnu ekonomiju i finansije, Trg kralja Aleksandra Ujedinitelja 11, 18000 Niš, Srbija. Znanstveni interes: financije, bankarstvo i osiguranje.Tel.: +38118528604.E-mail: srdjan.marinkovic@eknfak.ni.ac.rs. 